\title{
Correction to: Livek: A Mountainous Border Area's Transformation from a Ski Paradise to a Resilient Community
}

\author{
Mimi Urbanc and Mateja Šmid Hribar
}

\section{Correction to:}

Chapter 4: G. Martinez (ed.), Culture and Climate Resilience, Palgrave Studies in Climate Resilient Societies, https://doi.org/10.1007/978-3-030-58403-0_4

Owing to an oversight on authors' affilitation of this chapter were initially published with errors. The name of the institution that author is affilitated to is Research Centre and (not Center).

The updated version of this chapter can be found at https://doi.org/10.1007/978-3-030-58403-0_4

(C) The Author(s), under exclusive license to Springer Nature

Switzerland AG 2021

G. Martinez (ed.), Culture and Climate Resilience, Palgrave Studies in Climate Resilient Societies, https://doi.org/10.1007/978-3-030-58403-0_8 